\title{
Ansiedade, de Otto Stupakoff: uma análise semiótica
}

\section{PATRICIA KISS SPINELI \\ EDSON DO PRADO PFÜTZENREUTER}

\section{Resumo}

O artigo descreve e analisa a fotografia Ansiedade, do fotógrafo brasileiro Otto Stupakoff, e demais fotogramas da mesma sequência. A análise da fotografia foi feita sob o prisma da semiótica peirceana e permitiu discutir a respeito dos modos pelos quais as imagens produzidas conduzem a determinado interpretante (ou interpretantes). A análise da sequência, que inclui a fotografia Ansiedade, proporcionou subsídios para se realizar inferências em relação à poética de Stupakoff, que transparece no processo de escolha do fotógrafo diante do material imagético produzido.

Palavras-chave:

Fotografia, seleção fotográfica, semiótica peirceana 


\section{Otto Stupakoff's Anxiety: a semiotic analysis}

\section{PATRICIA KISS SPINELI \\ EDSON DO PRADO PFÜTZENREUTER}

\section{Abstract}

This paper describes and analyzes the photography Anxiety, by the Brazilian photographer Otto Stupakoff, and other frames of the same sequence. The analysis of this photography was made under Peircean semiotics, and allowed a discussion about the ways in which the produced images lead to certain interpretant (or interpretants). The analysis of the sequence that includes the photography Anxiety provided subsidies to infer Stupakoff's poetics, which appears in the photographer's selection process of the

Keywords: imagetic material produced. 


\section{Ansiedad de Otto Stupakoff: un análisis semiótica}

\section{PATRICIA KISS SPINELI \\ EDSON DO PRADO PFÜTZENREUTER}

\section{Resumen}

El artículo describe y analiza la fotografía Ansiedad, del fotógrafo brasileño Otto Stupakoff y demás fotogramas de la misma secuencia. El análisis de la fotografía se hizo bajo el prisma de la semiótica peirceana y permitió discutir acerca de los modos por los cuales las imágenes producidas conducen a determinado interpretante (o interpretantes). El análisis de la secuencia, que incluye la fotografía Ansiedad, proporcionó subsidios para realizar inferencias en relación con la poética de Stupakoff, que se revela en el proceso de selección del fotógrafo ante el material imagético producido.

Palabras clave:

Fotografía, selección fotográfica, semiótica peirceana 


\section{Introdução}

Otto Stupakoff (1935- 2009) foi um fotógrafo brasileiro pioneiro da fotografia de moda no Brasil. Ele consolidou sua carreira através das artes aplicadas e, como fotógrafo comissionado, registrou editorais de moda, capas de discos long play e publicidade. O resgate da obra do fotógrafo tem sido realizado pelo Instituto Moreira Salles (RJ), que adquiriu seu acervo - negativos em diferentes formatos, cromos, ampliações e folhas de contato - do período de 1955 a 2005.

Stupakoff utilizou a fotografia como expressão pessoal e criativa. Mesmo em trabalhos comissionados, procurava condições para a realização de obras autorais, da mesma forma que fotógrafos como Richard Avedon e Horst P. Horst (algumas de suas principais referências). Para Stupakoff, a fotografia de moda era a única que propiciava ao fotógrafo a oportunidade de se expressar tanto quanto uma ilustração, um trabalho editorial ou uma reportagem (FERNANDES JUNIOR, 2006).

Stupakoff foi um pioneiro na fotografia de moda no Brasil, tendo fotografado os publieditoriais da Rhodia ${ }^{1}$ e matérias para as revistas Cláudia e Joia. Posteriormente, alçou fama internacional por produzir ensaios fotográficos primorosos para as principais e mais conceituadas revistas especializadas em moda: Harper's Bazaar, Vogue, Glamour, Elle, Stern e Look Magazine.

Apesar de seu reconhecimento na moda, Stupakoff foi plural. Ao longo de sua atuação fotográfica, registrou viagens, família, nus e still life. Dentro de sua obra comercial e dos conjuntos menos conhecidos, também se encontra uma proposta de fotografia mais intimista, especialmente dedicada à figura feminina. É o caso da fotografia Ansiedade, Nova York, de 1990 (Figura 1). 


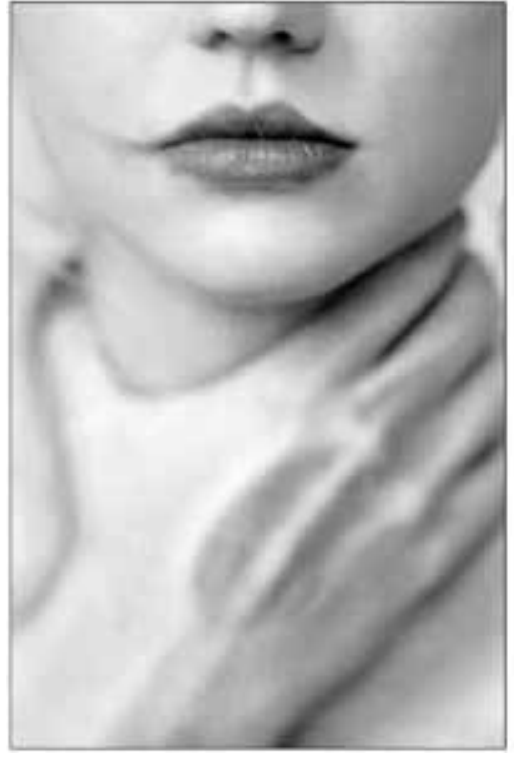

A fotografia Ansiedade faz parte do material fotográfico transferido por Otto Stupakoff ao Instituto Moreira Salles, no Rio de Janeiro, em 2008. A imagem foi exposta na $1^{a}$ edição da Coleção Pirelli/MASP de Fotografia e faz parte do acervo do MASP; também foi exposta em Moda sem fronteiras - Otto Stupakoff: 55 - 05, no evento São Paulo Fashion Week de 2005; no Instituto Moreira Salles, em São Paulo, Rio de Janeiro e Belo Horizonte em 2009 e Rio de Janeiro em 2016/2017; consta do acervo do Museu de Arte Moderna de São Paulo (MAM) e foi exposta nesse mesmo museu em Útero do mundo, 2016; está à venda em casas de leilões e galerias estrangeiras e brasileiras ${ }^{2}$, e foi publicada nos livros Otto Stupakoff (FERNANDES JUNIOR, 2006) e Sequências: Otto Stupakoff (INSTITUTO MOREIRA SALLES, 2009).

Pela análise do material de Stupakoff no Instituto Moreira Salles, constatamos que apenas o fotograma Ansiedade foi exposto, comercializado e incorporado em museus. Outros fotogramas da sequência ${ }^{3}$ que inclui Ansiedade (Figuras $2 \mathrm{~A}$ e 2B) podem ser vistos no livro Sequências Otto Stupakoff, editado e publicado pelo Instituto Moreira Salles em 2009. No entanto, a inclusão desses registros na publicação está mais atrelada à estrutura do livro, que se propõe a mostrar outras imagens de sequências", sob o viés de "tradição alternativa"5 (na apresentação de Wolfenson, 2009), do que à consagração desses outros fotogramas.
Figura 1: Otto Stupakoff, Ansiedade, Nova York, 1990.

Fonte: Sequências/Otto Stupakoff. São Paulo: Instituto Moreira Salles, 2009. 
Figura $2 A$ e $2 B$ : Otto Stupakoff, outros fotogramas da sequência de Ansiedade.

Fonte: Sequências/Otto Stupakoff. São Paulo: Instituto Moreira Salles, 2009.
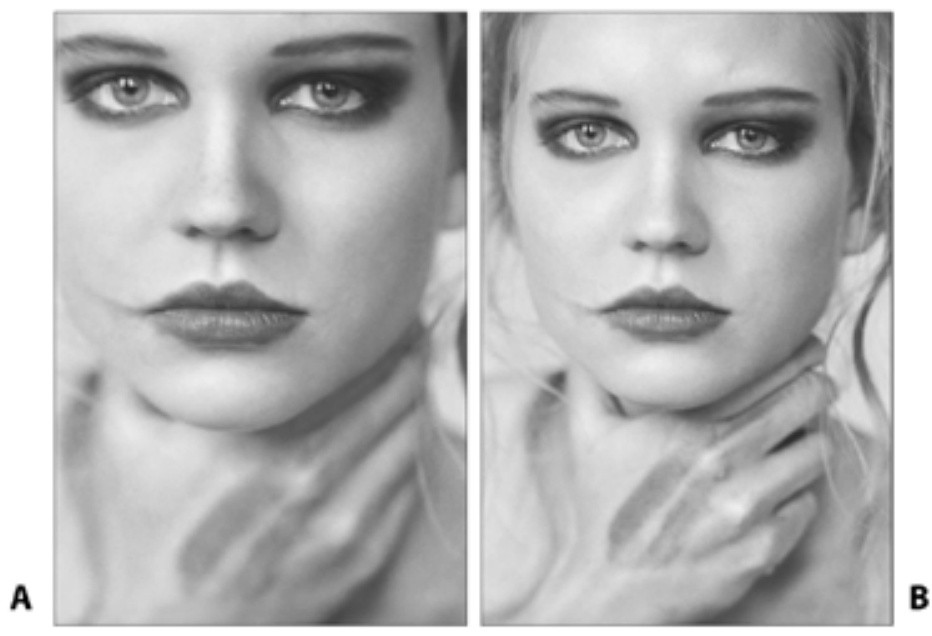

Constatamos também que existem outras sequências realizadas com a mesma modelo, exemplo de Homenagem a Balthus, da Coleção Pirelli/MASP6, 1991, e que apresentam distintas orientações de discurso.

A proposta do presente artigo é a de discutir a fotografia Ansiedade pelo viés da semiótica peirceana, visto que esse fotograma foi escolhido para ser apresentando ao público. Também é parte dos objetivos fazer uma correlação entre Ansiedade e as outras imagens não publicadas da mesma série fotográfica e, com isso, realizar inferências sobre a poética de Stupakoff.

A análise e a argumentação foram calcadas na observação da imagem e no que ela apresenta. O foco na detecção das características fenomenológicas da imagem foi importante, uma vez que não há outro recurso suficiente - como anotações, testemunhas ou depoimentos - que corroborem os procedimentos do fotógrafo no momento da realização do ensaio.

\section{Inferências sobre criação e seleção fotográfica}

Fotografar é uma ação que pressupõe perpetrar escolhas. A seleção, afirmação penetrante do fotógrafo, é um ato expressivo na fotografia. No modo em que cada fotógrafo dá o enfoque, são expressos seus motivos e distintos pontos de vistas. Nas palavras da fotógrafa Berenice Abbot: "A seleção de conteúdo apropriado à imagem vem da delicada união entre o olho adestrado e a mente com imaginação (ABBOT, 2007, p. 219). 
Essa seleção é inerente ao ato fotográfico e está baseada em um princípio organizador e individualizado: "organização disto que o fotógrafo tem em frente de si” (BECEYRO, 2003, p.125). Como princípio organizador, está o ato de eleger, dentre diversas possibilidades, a posição do fotógrafo/câmera em relação ao referente, pontos de vistas, enquadramento, modo de iluminar e composição, por exemplo.

Dentre as determinantes de escolha do fotógrafo, estão os aspectos objetivos e subjetivos (ENTLER, 2005), sendo que os elementos a serem fotografados, e que se transformarão em matéria fotográfica, irão projetar-se aos conteúdos subjetivos do fotógrafo.

O fotógrafo que busca imagens percorre seu campo de trabalho como quem revira um monte de sucatas em busca de uma peça que sirva a um novo fim proposto: recuperam-se fragmentos de visualidades muitas vezes não aproveitados pela atenção e análise dos observadores, por serem imperceptíveis ou desinteressantes, e se os apresenta num outro contexto (ENTLER, 2005, p. 280).

A elaboração de uma sequência de imagens no desenrolar do ato fotográfico é outro processo intrínseco à criação fotográfica. As várias tomadas de uma mesma cena fazem parte de um recurso de criação do fotógrafo. Segundo Entler (2005), assim como o pintor faz vários esboços antes da versão definitiva, o fotógrafo poderia fazer várias tomadas de uma mesma cena. No entanto, os vários fotogramas não correspondem a versões incompletas do que será a fotografia definitiva selecionada. Dependendo da postura do fotógrafo diante do que será fotografado, é possível que ele pense isoladamente cada fotograma sem tecer uma relação com os anteriores e posteriores, criando, dessa forma, imagens isoladas em um mesmo filme.

As sequências apresentam uma série de variantes possíveis de um mesmo acontecimento e podem ser vistas como possibilidade de registrar várias fotos em um breve intervalo de tempo. Posteriormente, essas fotos estarão sujeitas a escolhas que atendam às variadas intenções do fotógrafo ou de terceiros, sejam essas intenções conscientes ou não. No caso de Ansiedade, ficou evidente que a imagem-síntese é o fotograma 19 (Figura 1).

Abordamos aqui que a ação de eleger uma imagem, dentre diversas possibilidades, extrapola o ato fotográfico em si. Já 
existe uma seleção quanto ao assunto e como ele será fotografado, que se encerra no ato fotográfico, mas há uma ampliação do ato de escolha ${ }^{7}$ no momento em que um ou mais fotogramas de uma sequência são selecionados para serem apresentados ao público em forma de publicação ou exposição.

O processo de escolha do(s) fotograma(s) é diferente, dependendo do uso e da finalidade da imagem. Uma escolha artística é diferente de uma seleção para aplicação prática no design e na publicidade. Além disso, a consolidação da fotografia como portadora de uma linguagem própria e específica não impede que seu uso dialogue com outras linguagens (escrita, por exemplo), que muitas vezes influenciam na seleção e na edição final e, consequentemente, na escolha da imagem que virá a público.

Para Soulages (2005; 2010), são três as realidades que especificam a fotografia: as condições de possibilidades de uma foto, a foto em si e suas condições de obtenção da foto. A fotografia pode ser explicitada via estudo das condições de possibilidade de uma foto, que Soulages $(2005 ; 2010)$ delimita como correlato intencional de qualquer imagem fotográfica: o objeto a fotografar, o sujeito que fotografa e o material fotográfico. Desses três itens, a ênfase da discussão aqui apresentada está no material fotográfico per se, mais especificamente no que Soulages $(2005 ; 2010)$ classifica como terceira etapa, que é a escolha do fotograma que será ampliado, o trabalho com o negativo e a cópia da foto. A proposta aqui delineada se adequaria ao que Soulages classifica como a segunda maneira de analisar o trabalho do fotógrafo, que é a cisão entre o ato fotográfico e o trabalho com o negativo.

É notório que cada fotógrafo percebe a realidade e o assunto a ser fotografado de uma maneira particular, e esse modo de olhar fica expresso nas imagens registradas em uma sequência. Através da análise dessa sequência, podemos realizar algumas inferências quanto às características do olhar do fotógrafo perante a cena e a maneira como ele a fotografou. O editor do fotógrafo Josef Koudelka, em depoimento no documentário A grande tradição do fotojornalismo, Contatos, Vol.1, diz que, quando analisa as folhas de contato de Koudelka, "viaja no olhar do fotógrafo" (CONTATOS 1, 2015).

A visualização de uma sequência fotográfica pode ser viabilizada pela folha de contato ${ }^{8}$, que é um material impresso com os fotogramas do filme em miniatura, e as marcações na própria folha, indicando o que será ampliado, são um meio de materializar uma escolha. 
Bauret (1983) afirma que as verdadeiras respostas para a análise dos diferentes pontos de vista de um mesmo tema estão na folha de contato, que permite reconstruir e formular hipóteses sobre o método de trabalho do fotógrafo.

Desta forma, a análise da sequência através da folha de contato proporciona um vislumbre da visão fotográfica particular do fotógrafo, em que é possível observar o desenvolvimento espacial e temporal no ato do registro de um assunto específico, viabilizar a investigação sobre o desenrolar do assunto fotografado e presumir a conduta do fotógrafo em relação à cena. É através de notas referentes à composição, ao ângulo e ao enquadramento que podemos nos aproximar do olhar do fotógrafo perante seu objeto e propor como ele aborda a cena - esta é evidentemente uma conjectura, uma vez que somente o registro fotográfico impresso na folha de contato não permite a percepção de todas as motivações culturais e psicológicas de quem cria as imagens.

A folha de contato também pode ajudar o próprio fotógrafo a entender seu trabalho. Segundo o fotógrafo David Hurn:

As melhores imagens só ficam óbvias depois que você olha as folhas de contatos. A imagem poderia ser melhorada caso desse um passo para frente ou para trás? Qual seria o resultado caso tivesse tirado a foto um momento antes ou depois? (HURN apud LUBBEN, 2012, p.151).

Temos, então, que a folha de contato seria um meio mais direto e eficiente de analisar a sequência. No entanto, ela nem sempre está disponível. Algumas vezes o fotógrafo ou laboratorista não produz o copião, outras vezes este é descartado ou se tornou obsoleto (o que tem ocorrido no contexto contemporâneo devido ao processo fotográfico digital). Ainda assim, acreditamos ser admissível o uso de outros materiais que apresentem a sequência original9 - cópias para teste, por exemplo -, se em uma proposta de análise a folha de contato não estiver acessível.

Para cada imagem selecionada, outras foram "descartadas" e talvez nunca serão apresentadas ao público. Para o fotógrafo brasileiro Bob Wolfenson, quando uma imagem é selecionada para publicação em livros ou revistas, pode tornar-se consagrada e relegar ao esquecimento as demais que compunham a sequência original (INSTITUTO MOREIRA SALLES, 2009).

Há, então, uma ideia de abandono no processo de seleção da fotografia. As ideias foram materializadas no ato fotográfi- 
co, mas um processo seletivo elegeu somente uma ou algumas das imagens para serem reveladas e divulgadas.

Nem sempre as imagens não selecionadas falham em qualidades técnicas, expressivas ou de conteúdo. Por vezes, somente não se adequam em alguma proposta editorial, curatorial ou mesmo pessoal do fotógrafo e isso ocorre até mesmo quando essas propostas não estão explícitas ou conscientes. Nesse caso, a seleção pode ser verificada através de marcações perpetradas na folha de contato e também por informações vindas de outras fontes como depoimentos, diários e outras documentações do processo criativo que complementem o entendimento sobre a criação das imagens e dos motivos pelos quais estas foram divulgadas em detrimento das outras que foram registradas.

No trabalho de Stupakoff, toda a vinculação da sequência da qual Ansiedade faz parte ficou restrita ao fotograma 19 (Figura 1). Foi possível verificar as marcas materiais dessa escolha mediante acesso à tira de folha de contato (depositada no Instituto Moreira Salles). Nela, o fotograma 19 está assinalado por um retângulo vermelho e há uma anotação verbal confirmando a escolha. Essas anotações têm função pragmática de indicar o fotograma a ser divulgado como obra final.

\section{Ansiedade sob a luz da semiótica peirceana}

O conceito de signo foi sendo lapidado ao longo da vida de Charles Sanders Peirce e demonstrado a partir de diferentes perspectivas. Utilizamos a definição abaixo para fundamentar o presente trabalho ${ }^{10}$ :

Um signo, ou representamen, é aquilo que, sob certo aspecto ou modo, representa algo para alguém. Dirige-se a alguém, isto é, cria na mente desta pessoa um signo equivalente, ou, talvez, um signo mais desenvolvido. Ao signo assim criado denomino interpretante do primeiro signo. O signo representa alguma coisa, seu objeto. Representa esse objeto não em todos os seus aspectos, mas com referência a um tipo de ideia que eu, por vezes, denominei fundamento do representamen (PEIRCE, 1958, C.P. 2-228) ${ }^{11}$.

O signo é uma entidade vicária. Ele somente pode funcionar como signo se carregar o poder de representar ou substituir uma outra coisa diferente dele. Tudo depende de signos, até o pensamento, como nos diz Peirce (1958, C.P. 5-253): “Não 
podemos pensar sem signos". O pensamento é uma função sígnica interna da mente, mas exige um externalizar para que a semiose - "uma ação, ou influência que é, ou envolve, a cooperação de três elementos, tais como um signo, seu objeto e seu interpretante" (PEIRCE, 1958, CP. 5. 484) - possa envolver outras mentes. Assim, para desempenhar sua função comunicativa, o signo precisa estar materializado em um veículo sensível ou em uma forma expressiva (SANTAELLA, 2002), caso da fotografia.

O signo fotográfico pertence a um conjunto de significações e tradições que o definem como tal e faz parte de um sistema semiótico definido por um conjunto de leis e convenções. O sistema semiótico da fotografia inclui uma série de elementos que se repetem e que podem ser entendidos como códigos que estruturam a forma de a fotografia funcionar como signo. Podemos dizer, apropriando-nos da terminologia da linguagem verbal, que elementos como iluminação, ângulo, enquadramento e composição constituem a linguagem fotográfica.

Cada signo exibe uma singularidade e uma qualidade. A fotografia de uma casa e a palavra casa, ambas signos, se apresentarão de maneiras diferentes à mente de um receptor.

O objeto da semiótica está centrado no território da aparência, ou seja, no modo como o signo e a linguagem representam o objeto. Desse modo, a semiótica se ocupa do universo das representações e consequentemente da possibilidade de resgatar, nos fenômenos, sua densidade representativa, ou seja, representação é mediação que se situa entre o objeto, o mundo, o cotidiano e o intérprete. Logo, tudo é representável como condição de inteligibilidade do mundo e do próprio homem (FERRARA, 2004, p. 52 ).

Representar é um dos verbos que indicam a função do signo, mas também podemos dizer que o signo está para algo que é seu objeto e que, na relação entre signo e objeto, existem o objeto dinâmico e o objeto imediato (SANTAELLA, 2002; PLAZA, 2008). Esta distinção do objeto permite análises mais ricas sobre o processo de representação, pois prevê um objeto que está no signo (imediato) e outro que independe do signo (dinâmico).

O objeto dinâmico sempre escapa ao signo. Na fotografia Ansiedade (Figura 1), aqui analisada, é considerada somente a relação visual capturada no ato da tomada, i.e., a modelo, um 
ser humano do sexo feminino, que não está mais em frente a essa câmera e que provavelmente tem uma aparência diferente, pois existe um lapso de tempo entre o momento do registro e o momento em que essa foto é comentada.

Esta diferença temporal entre o objeto e o signo é crucial na fotografia. Barthes (1984), utilizando um outro embasamento teórico, traz uma explicação das diferenças entre os objetos na fotografia, ao mostrar o norte-americano Lewis Payne condenado à morte em 1865 com a legenda "Ele está morto e vai morrer" (BARTHES, 1984, p. 143). Está morto no momento em que vejo a foto, vai morrer quando a foto foi realizada.

O único objeto ao qual temos acesso é o imediato. Este é tal como representado no signo, i.e, tem uma função mediadora entre o signo e o objeto dinâmico. O objeto imediato em Ansiedade é o modo como a modelo está na imagem, a representação, através dos elementos da linguagem visual fotográfica, que destaca alguns aspectos da modelo e omite outros.

Ao aceitarmos a existência de um código da fotografia, ou mesmo uma linguagem visual fotográfica, não podemos deixar de destacar que este código inclui muitos elementos que existem em uma relação dinâmica. No caso de fotógrafos particulares, ou mesmo trabalhos fotográficos específicos, os elementos podem ser utilizados, aceitos, transgredidos, modificados ou inventados.

Para uma análise consistente da fotografia, é necessário pensar nos elementos da linguagem visual fotográfica não como autônomos, mas como fatores de um conjunto que resulta na imagem e estabelece uma estrutura, acondicionando-a em um contexto fotográfico. Ao se alterar o contexto, mesmo que minimamente, altera-se o significado. A mesma cena com um enquadramento mais aberto terá significado diverso com o enquadramento mais fechado.

Em Ansiedade temos: enquadramento em primeiro plano (close) com foco seletivo evidenciando o rosto e desfocando a mão e o pescoço; composição utilizando a regra dos terços que também é um elemento do código fotográfico - em que a mão e o pescoço ocupam os dois terços inferiores e o rosto o primeiro terço superior, e representação em preto e branco.

No processo comunicativo, pela face da significação ou da representação, é possível explorar o interior das mensagens quanto aos aspectos de qualidade de suas propriedades internas (linhas, formas, texturas, por exemplo), quanto ao seu contexto e quanto àquilo que a mensagem tem de convencional e cultural (SANTAELLA, 2002). Em Ansiedade, podem-se 
levantar os seguintes aspectos: (1) enquadramento fotográfico em close mostra elementos figurativos como parcial de um nariz, lábios, visão parcial de um pescoço e começo do tórax, uma mão em formato côncavo, somente sugerindo a pessoa fotografada; (2) imagem em preto e branco, com predomínio das nuances de cinza e meios-tons (3), e composição vertical e equilibrada, sem profundidade de campo, privilegiando uma mão que enlaça um pescoço. A descrição dos elementos que compõem a foto aponta ao leitor que se trata de um ser humano e, pelos traços corporais delicados convencionais, sugere um humano do sexo feminino (a modelo).

A fotografia, que é um signo formado a partir de outros signos, tem a mensagem visual como natureza. Como mensagem visual, no processo de conhecimento da imagem, é necessária a geração de uma série de interpretantes - processo conhecido como semiose - para que possamos inferir sobre alguns dos significados possíveis na imagem.

É importante notar que mesmo a percepção é entendida por Peirce como um processo sígnico que envolve primeiramente o fotógrafo. Ele estabelece seleções e relações em um repertório contextual. O leitor - público em geral, editor, curador, pesquisador -, no seu uso da foto, também terá uma percepção, fará correlações e estabelecerá um interpretante. O contexto é dado pelo fotógrafo que, em uma cadeia de signos, produzirá um signo que será apreendido e interpretado pelo leitor, i.e., o signo se faz no momento em que a foto é reconhecida como tal e dela depreenderá um interpretante.

A fotografia Ansiedade como signo, i.e., uma coisa que representa outra, está no lugar ou representando uma sensação, a sensação de ansiedade desencadeada por alguma emoção ${ }^{12}$. Assim, consideramos aqui que a semiose é um processo que ocorre no sentido do tempo, em uma regressão infinita, e do passado para o futuro. Essa regressão infinita nos permite recuperar a semiose ocorrida, algo pertinente à análise, visto que nossa preocupação é com o processo de signos que gerou a fotografia.

$\mathrm{Na}$ imagem, a mão enlaçando o pescoço sugere o ato de apertar. Existem aspectos de como a mão é apresentada - a saliência óssea e as veias saltadas -, que permitem a inferência de que os músculos estão retesados e, desta maneira, o pescoço estaria sendo pressionado. Essa imagem da mão é reforçada pelo contraste entre as linhas retas que a compõe e as curvas que estão no rosto, sendo que a representação da mão apertando o pescoço está associada simbolicamente ao sufocamento e ao estrangulamento. 
A palavra ansiedade vem do grego anshein e indica estrangular, sufocar, oprimir. A imagem da Figura 1 sugere que a própria pessoa causa esse estrangulamento, uma vez que, na representação, a modelo está emulando a sensação de aperto na garganta quando mecanicamente pressiona o pescoço com a mão.

O título refreia a polissemia inerente a qualquer imagem e reforça o direcionamento ao interpretante proposto no parágrafo acima. Na descrição de sintomas psicológicos, a ansiedade é um estado emocional desagradável, de medo e/ou apreensão, que vem acompanhado por desconforto devido à antecipação de estágios de perigo ou de algo que seja desconhecido (GENTIL, 1996). Entre os sintomas de um quadro ansioso, há alterações do sistema nervoso autônomo, coração acelerado e aperto no tórax e na garganta.

Ao que consta, o título Ansiedade foi atribuído a posteriori. Essa mesma imagem, quando exposta na $1^{\underline{a}}$ edição da Coleção Pirelli/MASP de Fotografia, foi intitulada Modelo e datada de 1989. Há um indicativo de que Stupakoff nomeou a fotografia a fim de efetivamente relacioná-la aos sintomas psicológicos. Em comunicação pessoal com o fotógrafo Fernando Laszlo, Stupakoff escreveu: "A palavra angústia em alemão, Angst, não ajuda a gente a melhorar"'s. Essa frase, que deveria acompanhar a fotografia na exposição da São Paulo Fashion Week 2005, não foi utilizada para esse fim. No entanto, ela nos permite inferir que Stupakoff atrela a palavra ansiedade à angústia, uma sensação psicológica que se caracteriza, entre outras coisas, pela opressão. Nada podemos afirmar quanto ao processo interior do fotógrafo, pois não é sabido se a ideia de estabelecer uma representação relacionada à sensação de ansiedade estava presente já no momento do registro da imagem - o uso de um título pretérito ao atual pode indicar que não foi esta a intenção primeira do fotógrafo.

Além do uso do substantivo abstrato no título, a constituição da imagem direciona nossa semiose. A maneira como a modelo está na imagem pode ser entendida como uma metáfora: estabelece-se uma conexão pela ideia entre a mão pressionando o pescoço e a sensação de sufocamento. A composição da fotografia e a forma como o signo representa aquele objeto são fundamentais por permitirem a geração destes interpretantes. Stupakoff registra a mão que enlaça o pescoço nos dois terços inferiores do enquadramento, o que possibilita atenção maior a essa área da imagem e evidencia a ação da mão envolvendo a garganta. 
No preto e branco, a expressão corporal é o que fica em evidência. O discurso em tons de cinza, ao suprimir a cor, evita que alguns dos elementos compositivos se destaquem pela vibração cromática. Os lábios são os únicos contrapontos e elementos de destaque. Pelo contraste, ficam em ênfase e dialogam visualmente com a mão.

A mão levemente desfocada promove a diluição das bordas dessa parte do corpo que quase se mescla ao pescoço. Essa mescla reforça visualmente a existência de uma força maior no ato de apertar.

O close do enquadramento mostra lábio, nariz e maxilar. Tal corte fechado exclui os olhos e impede a representação de um rosto em particular. Também sugere um rosto com aparência neutra, estabilidade e mesmo tranquilidade; isso, de forma contraditória, contrapõe-se ao estado ansioso.

As discussões apresentadas acima estão no âmbito do interpretante imediato, aquilo que o signo está apto a produzir em uma mente interpretadora qualquer (PEIRCE, 1958, CP. 8.343). O interpretante imediato indica a possibilidade de associar o ato da mão na garganta a um sintoma de ansiedade. Os signos, como este possível interpretante aparece na imagem, são comuns ao público em geral: o aperto na garganta e a mão simbolizando essa compressão, conjuntamente aos elementos da linguagem visual fotográfica discutidos acima (foco seletivo, enquadramento fechado e modo preto e branco), reforçados pelo verbal no título da imagem, direcionam para a formação na mente interpretadora de uma ideia associada à ansiedade.

Quanto ao interpretante dinâmico, aquilo que efetivamente será produzido na mente de cada intérprete, não podemos fazer inferências. Este depende do nível de repertório de cada leitor e, por ser múltiplo e plural, o interpretante dinâmico de um signo não se esgota em um único interpretante.

\section{Comparações entre a imagem escolhida e as outras da sequência}

Ao elencar, selecionar e estabelecer os elementos da fotografia, o fotógrafo está criando uma imagem resultante desse conjunto de ações. Esse conjunto estabelece a estrutura da imagem que, por sua vez, está dentro de um contexto fotográfico. As alterações de alguns elementos em cada um dos fotogramas de uma sequência estabelecem diferentes contextos fotográficos e, no geral, com todos os fotogramas da sequência, um 
conjunto de contextos, que contribuem para o interpretante da foto. Toda mudança de contexto altera esse interpretante.

Isso nos permite produzir um interpretante para cada imagem isolada da sequência e outro para o conjunto da sequência (mesmo que esses interpretantes se sobreponham). Queremos dizer aqui que a observação do todo pode sugerir outros interpretantes que a imagem isolada não traz. Essa outra maneira de olhar para o material do fotógrafo enriquece a análise da imagem isolada.

Nas Figuras $2 \mathrm{~A}$ e $2 \mathrm{~B}$, há alguns aspectos representativos semelhantes aos elencados na Figura 1: fotografia em preto e branco, foco parcial e close na face da modelo, por exemplo. O diferencial está na inclusão do olhar feminino que encara a câmera, na composição equilibrada - mão e olhar aparecem na mesma proporção e apresentam o mesmo peso visual - e nas variações de distância focal ${ }^{14}$ e de enquadramento.

Na Figura 2A, a modelo foi registrada em uma prismagem $^{15}$ mais afastada que proporciona a vista parcial do pulso, colo, cabelo e das orelhas. Na Figura 2B, o cabelo e pulso não são enquadrados, e a ênfase recai no rosto e na mão.

A necessidade de analisar todos os signos que compõem a imagem nos permite afirmar que o olhar da modelo é suficientemente expressivo para, no mínimo, partilhar com a mão no pescoço a atenção do leitor ou mesmo deslocar a atenção deste da mão para os olhos. A inclusão dos olhos na imagem amplia o processo de semiose e expande o rol de possíveis interpretantes.

Ainda existe a associação entre a mão apertando o pescoço à ansiedade, mas com uma força expressiva menor. Nessa linha argumentativa, a configuração da imagem no fotograma 19 (Figura 1) indica uma representação adequada à ideia de ansiedade, uma vez que o corte dado na linha do nariz não inclui os olhos da pessoa fotografada, ao mesmo tempo evidenciando a mão e o ato dela pressionando o pescoço.

As Figuras $2 \mathrm{~A}$ e $2 \mathrm{~B}$ não foram descartadas por falhas técnicas ou de construção do discurso; elas têm potencial técnico e conceitual para serem publicadas ou apresentadas ao público. Os fotogramas não apresentam significativos problemas quanto aos procedimentos técnicos fotográficos e foram registrados em exposição ideal: nem subexpostos, nem superexpostos $^{16}$. Em relação à construção da linguagem visual fotográfica, observa-se que os fotogramas não selecionados apresentam uma composição estruturada, harmonizando os elementos principais da linguagem fotográfica: enquadramento, luz, ângulo. 
No entanto, mesmo apresentando qualidades técnicas e conceituais, esses fotogramas não têm a força comunicativa para representar a ideia em questão (ansiedade). Reforçamos aqui que a força comunicativa da imagem escolhida (Figura 1) está na supressão do olhar da modelo, tornando-a enigmática a ponto de também permitir variadas intepretações, e no destaque da mão comprimindo o pescoço.

Por fim, em uma comparação conjunta das três imagens (Figura 3), verifica-se a experimentação no enquadramento. Stupakoff parte da captura de um plano mais fechado (aqui a apresentação está na ordem de tomada dos fotogramas), no qual somente boca e maxilar são apresentados, para um mais aberto em que o rosto preenche o quadro.
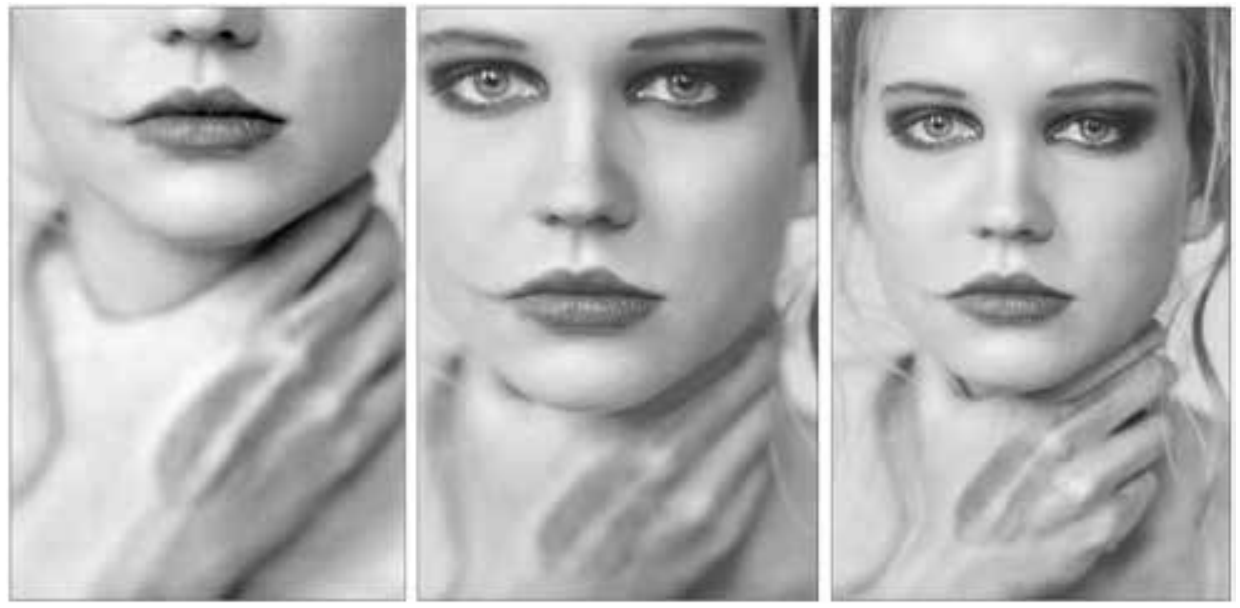

Essa pequena variação de enquadramento permite a Stupakoff explorar o referente imageticamente. Indica também o registro como salvaguarda de possibilidades de escolhas para o momento da edição em uma futura publicação. Segundo Wolfenson (apud INSTITUTO MOREIRA SALLES, 2009), na maioria dos casos, a captura de uma profusão de imagens de uma mesma cena é um método de trabalho que garante ao fotógrafo que a imagem procurada esteja à disposição dentre as muitas registradas.

Stupakoff compartilha da opinião de Wolfenson e diz "[...] na hora de escolher, que é a hora vital, eu tenho milhares daqueles slides ${ }^{17}$ " (STUPAKOFF apud FERNANDES JUNIOR, 2006, p.61). 


\section{Considerações finais}

No presente artigo foram apresentados e analisados, sob o viés da semiótica de Charles Sanders Peirce, os possíveis interpretantes da fotografia Ansiedade, de Otto Stupakoff. Foram abordados os aspectos do signo, assim como as faces da comunicação. Ao interpretante imediato, atribui-se a mão enlaçando o pescoço como uma representação da ideia de ansiedade através de uma associação entre o sintoma de sufocamento característico do ansioso e o sufocar representado na imagem.

Argumentamos que, no processo criativo fotográfico, existe a produção de sequências de imagens que acarretará em uma decisão e seleção do fotograma(s) a ser publicado(s) ou exposto(s). No entanto, o que não foi escolhido ainda é obra e tem potencialidades, de forma que o fotógrafo possa continuar o processo de optar e decidir após as imagens prontas.

Se a fotografia representa em seu conteúdo uma interrupção do tempo, sem outros fotogramas a lhe darem sentido (KOSSOY, 2001), é através da visualização de uma sequência que podem ser montados ou articulados determinados sentidos mais amplos do antes e depois daquela imagem fotográfica. A sequência também oferece possibilidades de se vislumbrar o contexto da realidade na qual a imagem foi registrada, salvo nas situações em que não se produziu um material para seleção.

Neste artigo, trabalhamos com os seguintes pressupostos: (1) nas sequências fotográficas é possível verificar quais fotos foram publicadas e as potencialidades técnicas e conceituais das que não foram; (2) as fotografias de uma sequência são indissociáveis de um complexo processo de criação do fotógrafo, que não se restringe à imagem entregue ao público, e (3) a análise objetiva das sequências é uma das formas para se estudar o olhar e as intenções do fotógrafo durante o ato fotográfico.

Ansiedade é parte de um conjunto de outras imagens. A análise do conjunto possibilitou uma noção diferenciada em relação à análise individual. A apresentação das outras duas fotografias da mesma série permitiu o levantamento de inferências sobre os motivos da seleção de uma determinada imagem em detrimento das outras. Sugere-se aqui que o fotograma selecionado para divulgação/publicação indica aspectos que orientam as escolhas poéticas do fotógrafo. Em Ansiedade, foram apresentados elementos da linguagem visual fotográfica que representam sugestivamente o tema e expressam a ideia proposta pelo título da fotografia. 
NOTAS

1 Empresa francesa que atua no Brasil desde 1919 e pioneira na produção do fio sintético no país desde o final da década de 1950.

2 Pequena Galeria Mario Cohen. Disponível em: <http://galeriamariocohen. com.br/?page_id=21729\#prettyPhoto $>$.

3 Uma sequência fotográfica diz respeito ao encadeamento de fotogramas realizados seguidamente em um suporte físico (filme) ou digital. Esse encadeamento pode apresentar o desenvolvimento de um ensaio ou tema fotográfico, assim como pode também apresentar imagens dispersas.

4 Estão contidas nesse livro outras sequências de Stupakoff.

5 Tradição alternativa no sentido de que outros fotógrafos, vez ou outra, tornam públicas suas sequências.

6 Essa imagem pode ser vista em: <http://www.colecaopirellimasp.art.br/ autores/17>.

7 Para abordar a seleção e a edição, partiremos dos seguintes conceitos: selecionar é uma operação de escolha que se materializa inicialmente na marcação das opções pretendidas e editar é preparar para a publicação. Editar fotografias pode ser também no sentido de adequar, modificar, interferir.

8 Também conhecida como folha de prova ou copião, sua função é servir como ferramenta de edição e índice para arquivos de negativos, além de oferecer ao fotógrafo a primeira visão do que havia sido capturado no filme.

9 Para a análise deste trabalho, recorremos às folhas de contato de Otto Stupakoff presentes no acervo do Instituto Moreira Salles.

1o Um levantamento feito por Robert Marty identificou 76 diferentes definições e acrescentou mais 12 possibilidades.

11 Todas as referências no texto da obra The collected papers, de Peirce, foram feitas sob a sigla $\mathrm{CP}$, seguida do número do volume e número do parágrafo.

12 Segundo Savan (1981), emoção também é signo no sentido que ela pode representar algo que foi sentido em um determinado evento. Um evento idêntico não pode voltar a ocorrer, mas as emoções sim.

13 Comunicação pessoal de Otto Stupakoff, em 2005, recebida via correio eletrônico por Fernando Laszlo.

14 A distância focal é a distância entre o centro óptico (no meio da lente) e a superfície sensível (o sensor ou filme) na câmera. Ela é responsável por estabelecer o ângulo de visão. Quanto maior a distância focal, maior a aproximação do objeto alvo e vice-versa.

15 Seleção de um detalhe que obedece às regras de redução e ampliação.

16 Subexposta: quando não há luz suficiente incidindo no material sensível para formar a imagem e esta fica escura. Superexposta: quando há excesso de luz incidindo no material sensível para formar a imagem e esta fica clara.

17 Conhecidos também como diapositivo. Filme em positivo.

\section{AGRADECIMENTOS}

Agradecemos ao Instituto Moreira Salles pelo acesso ao acervo de Otto Stupakoff e a Charles Morphy D. Santos pela revisão. 


\section{Referências}

ABBOTT, Berenice. La fotografia en la encrucijada (1951). In: FONTCUBERTA, Joan (Ed.). Estética fotográfica: una selección de textos. Barcelona: Editorial Gustavo Gili, 2007.

BARTHES, Roland. A câmara clara. Tradução Júlio Castañon Guimarães. São Paulo: Editora Nova Fronteira, 1984.

BAURET, Gabriel. Les traces d'une méthode. Les Cahiers de la photographie, Paris, n.10, 1983.

BECEYRO, Raúl. Ensayos sobre fotografia. Buenos Aires: Paidós, 2003.

CONTATOS 1, a grande tradição do fotojornalismo. Produção de La Sept Arte, KS

Visions, RIFF Internacional e Centre National de la Photographie, a partir de uma ideia de William Klein/França 1990-2002. Rio de Janeiro: Instituto Moreira Salles distribuição, 2015. 1 DVD (156 min), color.

ENTLER, Ronaldo. Fotografia e acaso: a expressão pelos encontros e acidentes. In: SAMAIN, Etienne. O fotográfico. 3 ed. São Paulo: Editora Hucitec/Editora Senac, 2005.

FERNANDES JUNIOR, Rubens (Org.). Otto Stupakoff. São Paulo: Cosac Naify, 2006.

FERRARA, Lucrécia D’Alessio. Do desenho ao design: um percurso semiótico?. Galáxia, n.7, 2004

GENTIL, Valentim. Ansiedade e transtornos ansiosos. In: GENTIL, Valentim; LOFUTO, Francisco Neto (Org.). Pânico, fobias e obsessões: a experiência do projeto Amban. São Paulo: Edusp, 1996. p. 17-30.

INSTITUTO MOREIRA SALLES (Org.). Sequências/Otto Stupakoff : apresentação de Bob Wolfenson. São Paulo: Instituto Moreira Salles, 2009.

KOSSOY, Boris. Fotografia e história. São Paulo: Ateliê Editorial, 2001.

LUBBEN, Kristen (Org.). Magnum: contatos. Tradução Jorio Dauster. São Paulo: Instituto Moreira Salles, 2012.

MARTY, Robert. 76 definitions of The Sign by C. S. Peirce. Disponível em: <http://www.iupui.edu/ arisbe/ rsources/76DEFS/76defs.HTM>. Acesso em: 14 abr. 2017.

PEIRCE, Charles Sanders. The collected papers. Cambridge-Massachusetts: Harvard University Press, 1958. 8 vols.

PLAZA, Júlio. Tradução intersemiótica. São Paulo: Editora Perspectiva, 2008.

SANTAELLA, Lúcia. Semiótica aplicada. São Paulo: Thomson Learning, 2002. 
SAVAN, David. Peirce's semiotic theory of emotion. In:

Proceedings of the C.S. Peirce Bicentennial International

Congress. Lubbock: Texas Tech Press, 1981, p. 319-334.

SOULAGES, François. A fotograficidade. Revista Porto Arte,

Porto Alegre, v. 13, n. 22, 2005.

. Estética fotográfica: perda e permanência. São Paulo:

Senac, 2010. 
Recebido em: 21/04/2017

Aprovado em: 18/12/2017

\section{PATRICIA KISS SPINELI}

kissspineli@gmail.com

Doutora em Artes Visuais pela Unicamp (2017). Mestre em Design pela Unesp (2013). Especialista em Fotografia pela Universidade Estadual de Londrina (2008). Graduada em Desenho Industrial pela Unesp (2003). Leciona para os cursos de graduação em Fotografia, Design Gráfico e Artes Visuais.

\section{EDSON DO PRADO PFÜTZENREUTER}

edson.reuter@gmail.com

Doutor em Comunicação e Semiótica pela PUC - SP (1997). Mestre em Comunicação e Semiótica pela PUC - SP (1992). Graduado em Educação Artística - Artes Plásticas pela USP (1985). Professor da graduação e pós-graduação do Instituto de Artes da Unicamp. 